\title{
Application of luminescence method for estimation of herbicide phytotoxicity
}

\author{
STANISLAW GWIZDEK ${ }^{1}$, ANTONI MURKOWSKI ${ }^{2}$, ELŻBIETA SKORSKA ${ }^{2}$ \\ ${ }^{1}$ Department of Plant Physiology, Agricultural University, ul. Słowackiego 17, 71-434 Szczecin, \\ Poland \\ ${ }^{2}$ Laboratory of Biophysics, Department of Physics, Agricultural University, ul. Janosika 8, 71-424 \\ Szczecin, Poland
}

$\langle$ Received: May 16, 1983〉

\begin{abstract}
Results of research on the applicability of the luminescence method for estimation of phytotoxicity of herbicides inhibiting photosynthesis 〈atrazine, terbutrine, linuron〉 are presented. This method was tested on wheat, barley and oat seedlings. Measurements of dry weight and photosynthesis intensity were done for comparison. The results show the possibility of replacing standard methods by the luminescence test since it is easier to perform and more precise than the standard ones.
\end{abstract}

\section{INTRODUCTION}

The wide application of herbicides in agriculture and horticulture requires the elaboration of rapid and simple methods of assay of their phytotoxicity, accessibility to the protected plants and weeds and an easy determination of the herbicide residue in the soil.

From among the widely applied soil herbicides an important role is played by urea derivatives, triazine and diazine, which are inhibitors of electron transport in the photosystem II. Their phytotoxic action is mainly manifested in blocking the water photolysis reaction $\langle\mathrm{A} \mathrm{s} \mathrm{s} \mathrm{c} \mathrm{he} \mathrm{and} \mathrm{Carle} \mathrm{s}, 1982 ; \mathrm{Cz} \mathrm{u} \mathrm{c} \mathrm{h} \mathrm{a-}$ jow s k a and W oj t a s z e k, 1971; P ło s z yn s k i, 1967). The photosynthesis process is accompanied by red luminescence the intensity of which and kinetics may supply much information on the normal function of both photosystems, and indirectly on the influence of various physico-chemical factors on the plant organism $\langle\mathrm{S}$ we e t s e $\mathrm{r}$ et al., 1961; $\mathrm{S} \mathrm{h} \mathrm{u} \mathrm{v} \mathrm{a} \mathrm{lov} \mathrm{and}$ Li t vi n, 1969).

Disorders in the course of the water photolysis reaction by herbicides cause characteristic changes in luminescence decay recorded in a time longer than $1 \mathrm{~s}$ 
after switching of the light. This phenomenon was utilized to evaluate the effect of herbicides on crop plants and weeds, and also to determine the herbicide residues in the soil and water $<\mathrm{M} \mathrm{u} \mathrm{r} \mathrm{k} \mathrm{ow} \mathrm{s} \mathrm{k} \mathrm{i,} \mathrm{1973,} \mathrm{1975b;} \mathrm{M} \mathrm{u} \mathrm{r} \mathrm{k} \mathrm{o} \mathrm{w} \mathrm{s} \mathrm{k} \mathrm{i} \mathrm{and}$ B r z ó s t ow i c z, 1980; S ok o l o v et al., 1974 $\rangle$.

\section{MATERIAL AND METHODS}

\section{Material}

Three herbicides were used in the tests: Gesaprim $50-$ a triazine herbicide containing 50 per cent of atrazine, Igran 50 - a triazine preparation with 50 per cent terbutrine, Afalon - a herbicide on the basis of urea containing 50 per cent linuron.

The influence of these herbicides was tested on three kinds of cereals: oats $\langle$ Avena sativa $\rangle \mathrm{cv}$. 'Udycz', barley $\langle$ Hordeum sativum $\rangle \mathrm{cv}$. 'Śląski II' and wheat $\langle$ Triticum sativum > cvs. 'Mironowska 808', 'Grana' and 'Maris Huntsman'.

The tests were carried out with 4-6-day-old seedlings growing in hydroponic cultures. The plants grew at $21^{\circ} \pm 2^{\circ} \mathrm{C}$ under white fluorescent light <intensity ca. $100 \mathrm{~W} / \mathrm{m}^{2}$ in the FAR range $>$ and a photo period of $12 \mathrm{~h} / 12 \mathrm{~h}$. The control plants were watered with Hoagland's medium diluted with water in a $1: 1$ ratio. The test plants received diluted medium with herbicides added in the specified concentrations.

Part of the oat 'Udycz' plants were sown in paraffin-coated containers with $100 \mathrm{~g}$ of air-dry light, medium and heavy soil. Herbicides were introduced into this soil in such amounts as to obtain a $2,4,8,16,32 \mu \mathrm{g}$ concentration per $0.1 \mathrm{~kg}$ of soil. The oat plants grew for 14 days at controlled temperature $\left\langle 21^{\circ} \pm 2^{\circ} \mathrm{C}\right\rangle$ under fluorescent light 〈"day"〉 of $35 \mathrm{~W} / \mathrm{m}^{2}$ intensity in the FAR range and photoperiod $10 \mathrm{~h} / 14 \mathrm{~h}\langle$ day/night $\rangle$.

Part of the plants of the wheat varieties were seeded in containers with light soil, placed in the glasshouse and watered with a water suspension of the herbicides in the amount of $7.5 \mathrm{mg}$ per $500 \mathrm{~cm}^{2}$ of soil surface in the container, this corresponding to a dose of $1.5 \mathrm{~kg} / \mathrm{ha}$. Each container was filled with $10 \mathrm{~kg}$ of air-dry soil. The glasshouse temperature was $22^{\circ} \pm 2^{\circ} \mathrm{C}$, light was natural $\langle$ October $\rangle$, the plants grew there for 21 days.

\section{Methods}

\section{A. Delayed luminescence measurement}

Delayed luminescence was measured by means of a system with a photomultiplier EMI 9558B <M u r k ow s k i, 1975b; $\mathrm{M} \mathrm{u} \mathrm{r} \mathrm{k} \mathrm{ow} \mathrm{s} \mathrm{k} \mathrm{i} \mathrm{and}$ B r z ó s t o w i c z, 1980 $>$. For a single measurement one sample consisting of three cut blades of the first leaf of about $2.5 \mathrm{~cm}$ lenght each were taken, and in tests with oats the whole container with about 10 plants was a single sample. 
The course of measurement is illustrated in Figure 1. After $4 \mathrm{~s}$ of illumination with the projection lamp 〈ca. 4 lux $\rangle$ there is a $2 \mathrm{~s}$ interval during which the photomultiplier is opened. During the next $2 \mathrm{~s}$ counting of voltage pulses takes place on the photomultiplier output. The number of counted pulses $n_{1}$ is proportional to the luminescence intensity of the illuminated plant tissues containing chloroplasts. After the successive $6 \mathrm{~s}$ the result of the previous count is erased and the next measurement of light intensity takes place. In this way four readings are obtained $\left\langle\mathrm{n}_{1}, \mathrm{n}_{2}, \mathrm{n}_{3}\right.$ and $\left.\mathrm{n}_{4}\right\rangle$ showing the decay of delayed luminescence of the tested plant.

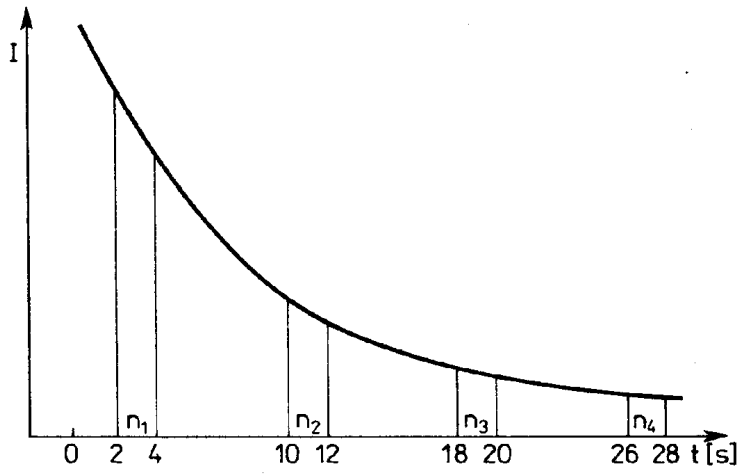

Fig. 1. Example of delayed luminescence decay

The values $n_{1} \ldots n_{4}$ decrease under the influence of substances inhibiting photolysis reactions 〈e.g. some herbicides〉, the more distant ones disappearing quicker. Therefore, the $n_{2} / n_{1}$ ratio of the poisoned plant is lower than that of the control one. As measure of phytotoxicity was assumed the dimensionless parametre $\langle w\rangle-$ the quotient $w_{\text {exam. }}$ of the tested object and $w_{\text {contr. }}$, calculated for the control plant:

$$
\mathrm{w}=\frac{\mathrm{w}_{\text {exam. }}}{\mathrm{w}_{\text {contr. }}} 100 \%=\frac{\mathrm{n}_{2} / \mathrm{n}_{1 \text { exam. }}}{\mathrm{n}_{2} / \mathrm{n}_{1 \text { contr. }}} \cdot 100 \%
$$

B. Photosynthesis intensity measurement

Photosynthesis intensity was measured by means of the $\mathrm{CO}_{2}$ analyser Infralyt IV operating in an open system. The examined plants were placed in thermostated $\left\langle 25^{\circ} \mathrm{C}\right\rangle$ containers of organic glass and illuminated with two mercury lamps of IRFR 400 type. The lamps illuminated the plants at an intensity of $120 \mathrm{~W} / \mathrm{m}^{2}$ in the FAR range $\langle\mathrm{M} \mathrm{u} \mathrm{r} \mathrm{k} \mathrm{o} \mathrm{w} \mathrm{s} \mathrm{k} \mathrm{i,} \mathrm{1975b;} \mathrm{O} \mathrm{l} \mathrm{e} \mathrm{c} \mathrm{h,} \mathrm{1969}\rangle$. 


\section{Dry weight measurement}

For dry weight determination of the plants the above ground parts were cut after 15 or 21 days of growth, dried at $105^{\circ} \mathrm{C}$ to constant weight. The measurements were done with an accuracy up to $1 \mathrm{mg}$.

The luminescence tests and photosynthesis intensity measurements in the cereal seedlings were repeated four times. The errors of the means of index $\langle w\rangle$ calculated by Student's t-test at the significance level 5 per cent did not exceed 12 per cent, whereas the errors in dry weight measurement reached 18 per cent and those of photosynthesis intensity 30 per cent.

\section{RESULTS}

The present results demonstrated that the effectiveness of the phytotoxic action of the herbicide preparations depends on the kind of soil 〈Fig. 2, Table 1〉, and particularly on the sorption complex of the soil and humus content. The

$$
\text { T a ble } 1
$$

Mechanical composition and humus content in investigated soils

\begin{tabular}{|c|c|c|c|c|}
\hline \multirow{2}{*}{ Soils } & \multirow{2}{*}{$\begin{array}{c}\text { Humus } \\
\text { content } \\
(\%)\end{array}$} & \multicolumn{3}{|c|}{$\begin{array}{c}\text { Content of soil fractions } \\
(\%)\end{array}$} \\
\hline & & $\begin{array}{c}1.00-0.05 \\
\mathrm{~mm}\end{array}$ & $\begin{array}{c}0.05-0.005 \\
\mathrm{~mm}\end{array}$ & $\begin{array}{c}>0.005 \\
\mathrm{~mm}\end{array}$ \\
\hline Heavy soil - A & $\mathbf{3 . 0}$ & 35 & 27 & 38 \\
\hline Medium soil - B & 1.4 & 68 & 15 & 17 \\
\hline Light soil - C & 0.7 & 76 & 18 & 6 \\
\hline
\end{tabular}

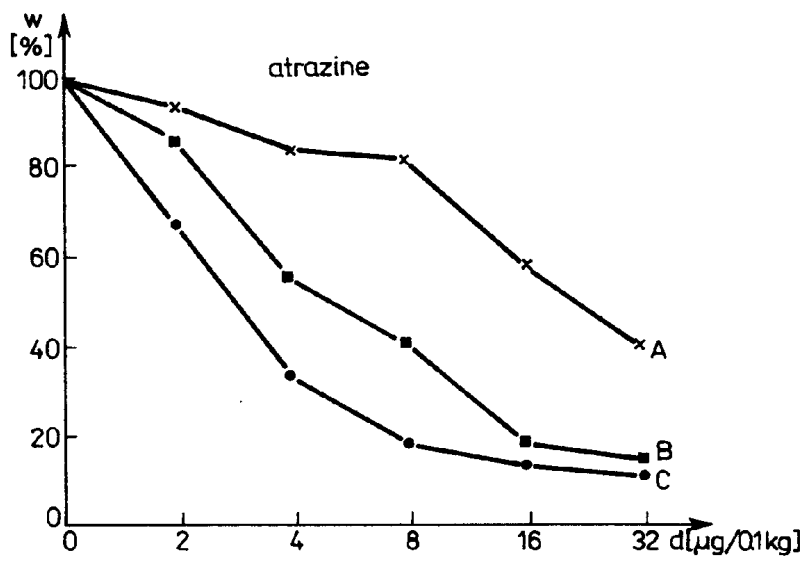

Fig. 2. Relationship between coefficient $\langle w\rangle$ and atrazine dose for oat seedlings growing on heavy $\langle A\rangle$, medium $\langle B\rangle$ and light $\langle C\rangle$ soils. The values $\langle w\rangle$ are expressed in $\%$ of control. Measurements were done during the fourth day after herbicide application 
atrazine doses applied on heavy soil $\langle\mathrm{A}\rangle$ caused the smallest changes in index $\langle w\rangle$. Higher doses than $2 \mathrm{mg} / 0.1 \mathrm{~kg}$ in medium and light soil $\langle\mathrm{B}$ and $\mathrm{C}\rangle$ produce a considerable increase in the rate of decay of delayed luminescence, this corresponds to a marked diminution of the $\langle w\rangle$ index.

It is seen in Figure 3 that, of the three parametres, photosynthesis intensity and index $\langle w\rangle$ have similar courses and seem to be more sensitive indices of the increasing doses of atrazine in the soil than the decrease of dry weight in oat plants.

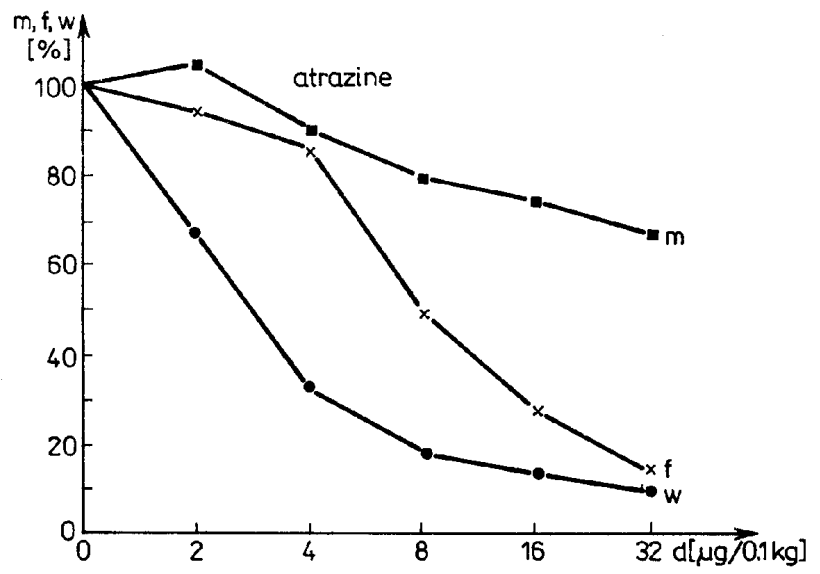

Fig. 3. Relationship between photosynthesis intensity $\langle\mathbf{f}\rangle$, coefficient $\langle w\rangle$, dry weight $\langle\mathrm{m}\rangle$ and atrazine dose for oat seedlings growing on light soil. Measurements of photosynthesis intensity and delayed luminescence were done during the fourth day after herbicide application and dry weight was measured after fourteen days. All values are expressed in \% of control

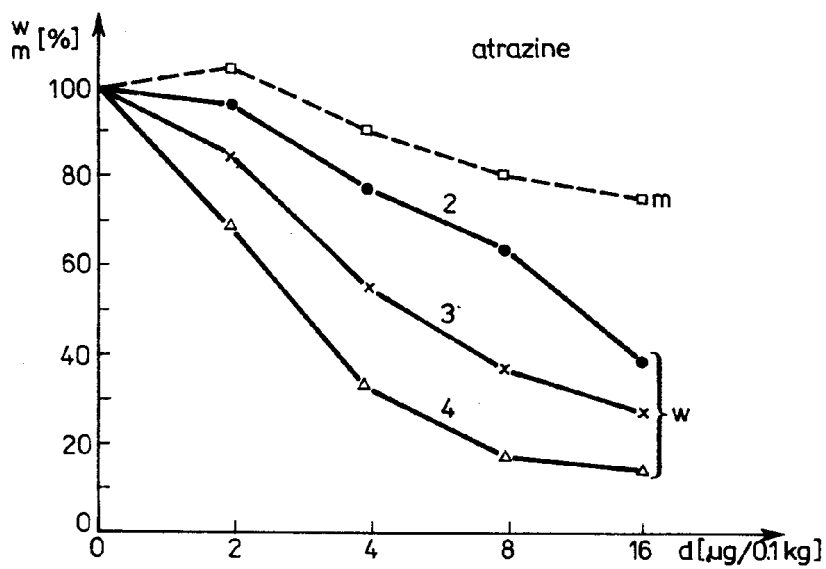

Fig. 4. Values of coefficient $\langle w\rangle$ measured after 2, 3, 4 days of atrazine action on oat seedings growing on light soil. Dashed line - dry weight $\langle\mathrm{m}\rangle$ measured after 14 days of atrazine action. The values of $\langle w\rangle$ and $\langle m\rangle$ are expressed in $\%$ of control 
The action of herbicides on plants becomes much more pronounced in the changes of the $\langle w\rangle$ index values than could be inferred from dry mass measurement $\langle\mathrm{M} \mathrm{u} \mathrm{r} \mathrm{k} \mathrm{o} \mathrm{w} \mathrm{s} \mathrm{k} \mathrm{i,} \mathrm{1975a,} \mathrm{b}\rangle$. This has been confirmed by the results of investigation with the use of various atrazine concentrations acting on oat seedlings $\langle$ Fig. 4$\rangle$. Comparison of the course of parametres $\langle m\rangle$ and $\langle w\rangle$ $\langle$ after 2, 3 and 4 days $\rangle$ shows that the luminescence test requires a several times shorter time and is much more sensitive.

Assay of the susceptibility of three wheat varieties to terbutrine was done by the earlier described methods. The results of investigations $\langle$ Fig. 5$\rangle$ indicate that the 'Grana' does not tolerate well terbutrine.
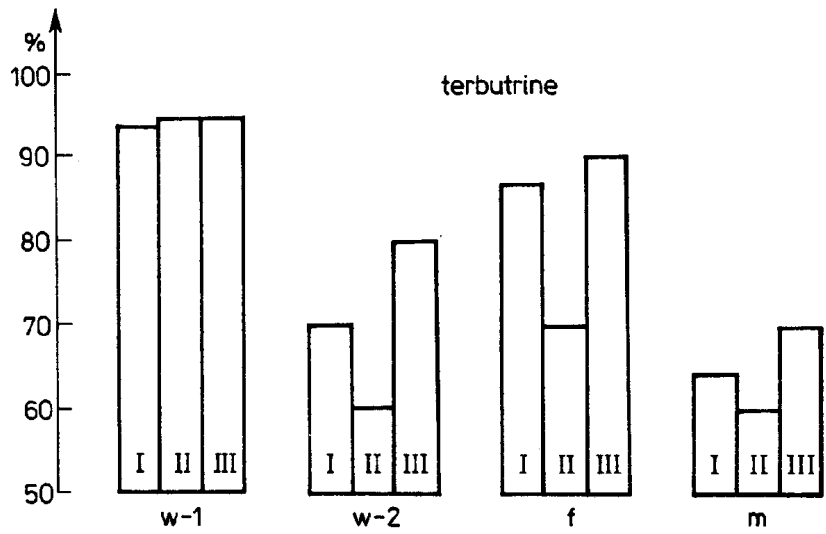

Fig. 5. Comparison of delayed luminescence decay coefficient after 1 day $\langle w-1\rangle$ and 2 days $\langle w-2\rangle$ of terbutrine action $\langle$ concentration $-0.5 \mathrm{ppm}\rangle$ with photosynthesis intensity $\langle\mathrm{f}\rangle$ after 1 day of herbicide action $\langle$ concentration $-0.5 \mathrm{ppm}\rangle$ and dry weight $\langle\mathrm{m}\rangle$ after 21 days of wheat seedlings growth in soil with herbicide in concentration $7.5 \mathrm{mg} / 500 \mathrm{~cm}^{2}=1.5 \mathrm{~kg} / \mathrm{ha}$. All values are expressed in

$\%$ of control. I - 'Mironowska 808', II - 'Grana', III - 'Maris Huntsman'

The influence of some herbicides on cereal seedlings growing in hydroponic culture was also investigated. Comparison of the effect of atrazine and linuron on young plants $\langle$ Table 2$\rangle$ shows that the percentual changes in the $\langle w\rangle$ and $\langle f\rangle$ values are similar, and the luminescence test is characterized by smaller dispersion of mean values.

Table 2

Comparison of delayed luminescence decay data with photosynthesis intensity after $24 \mathrm{~h}$ of atrazine and linuron action on barley seedlings in hydroponics

\begin{tabular}{lllllll}
\hline & \multicolumn{2}{c}{ Atrazine } & & \multicolumn{2}{c}{ Linuron } \\
\cline { 2 - 3 } \cline { 5 - 6 } $\begin{array}{c}\text { Investigated } \\
\text { parameters }\end{array}$ & $0.5 \mathrm{ppm}$ & $5.0 \mathrm{ppm}$ & & $0.5 \mathrm{ppm}$ & $5.0 \mathrm{ppm}$ \\
\cline { 6 - 7 } & $40 \pm 1$ & $7 \pm 0.1$ & & $76 \pm 7$ & $50 \pm 6$ \\
w $(\%)$ & $48 \pm 10$ & $8 \pm 11$ & & $85 \pm 14$ & $64 \pm 13$ \\
f $(\%)$ & $4 \%$ & &
\end{tabular}




\section{CONCLUSIONS}

1. The present investigations confirmed the possibility of applying the luminescence method for estimation of the phytotoxicity of herbicides photosynthesis inhibitors.

2. The luminescence method is characterized by a small dispersion of the result values in the series of measurements and is little time-consuming as compared with dry weight and photosynthesis intensity measurements.

\section{REFERENCES}

A s s c h e C. J., C a r l e s P. M., 1982. Photosystem II inhibiting chemicals $\langle$ In: $\rangle$ D. E. Moreland, J. B. St. John, F. D. Hess $\langle$ ed. $\rangle$ Biochemical responses induced by herbicides. American Chemical Society, Washington pp. 1-21.

C z u chajowska Z., Wojt a s zek T., 1971. Drogi i mechanizmy oddzialywania herbicydów pochodnych mocznika na fizjologiczne i biochemiczne procesy organizmów roślinnych. Post. Nauk Rol. 6: 37-70.

M u r k o w s k i A., 1973. Use of standard radiometric systems in the photosynthetic luminescence of cultivable plants and the weeds. Prace I. S. Skierniewice, ser. E, 3: 595-606.

M u r k owsk i A., 1975a. Ocenka fitotoksichnosti gerbicidov - proizvodnykh mocheviny i triazina luminescentnymi metodami. 〈In:〉 Mechanizm dejstvija gerbicidov i sinteticheskikh regulatorov rosta rastenii i ich sud'ba v biosfere. AN ZSRR, Pushchino: 187-193.

M u r k ow s k i A., 1975b. Luminescencyjne metody badania wpływu herbicydów na organizmy fotosyntetyzujące. Praca doktorska. Akademia Rolnicza, Szczecin.

M u r k ow s k i A., B r z ó s t o w i c z A., 1980. Luminescencyjna metoda oznaczania pozostałości herbicydów -inhibitorów fotosyntezy w glebie i wodzie. 〈In:〉Biofizyka 〈prace doświadczalne $>$, WSRP, Siedlce: 157-175.

O 1 e c h K., 1969. Wpływ niektórych herbicydów na fotosyntezę i oddychanie roślin. Rozprawa habilitacyjna. WSR, Lublin.

P ło s z y ń s k i M., 1967. Herbicydy s-trójazynowe - niektóre ich własności i działanie na metabolizm rośliny. Post. Nauk Rol. 5: 94-100.

S ok o lov M. S., M o c h a $1 \mathrm{k}$ i n A. I., A l e k s e v S. I., 1974. Narushene fotoinducirovannogo svecheniya rastenii pod dejstviem gerbicidov $\langle\mathrm{In}:\rangle$ Sverkhslabye svecheniya $v$ medicine i selskomkhozaistve. Pr. Zb. Izd. MGU, Moskwa.

S w e e t s e r P. B., T o d d C. W., H e r s h R. T., 1961. Effect of photosynthesis inhibitors on light re-emission in photosynthesis. Biochim. Biophys. Acta 51: 509-518.

S h u v a 1 o v V.A., L i t v i n F. F., 1969. O mekhanizme dlitelnogo poslesvechenia listev rastenii i zapasanii energii $v$ reakcionnykh centrakh fotosinteza. Mol. biol. 3: 1, 59-73.

Zastosowanie metody luminescencyjnej do oceny fitotoksyczności niektórych herbicydów

\section{St reszczen i e}

Przedstawiono wyniki badań nad zastosowaniem metody luminescencyjnej do oceny fitotoksycznego wpływu herbicydów - inhibitorów fotosyntezy 〈atrazyny, terbutryny i linuronu〉 na siewki pszenicy, jęczmienia i owsa. Jako metody porównawcze zastosowano pomiary suchej masy oraz intensywności fotosyntezy. Uzyskane rezultaty wskazują na możliwość zastąpienia metod standardowych testem luminescencyjnym. 